In contrast, those courts which find a crime in the debt and security situations emphasize the protective as well as the punitive function of the criminal law. The argument made is that persons who are willing to collect their debts by frauds, or who are so desperate to gain a loan as to misrepresent the value of the proffered collateral are as punishable as those who tangibly injure their victims. Thus:

[T] he proper consideration is, is it safe to allow every man to be a judge in his own cause, and, in officiating in that capacity, to allow him to resort to false pretenses to accomplish his purpose? ${ }^{17}$

This right [of obtaining the payment of debts by false pretenses] would be inconsistent with the peace and good order of society, which it is one of the principal purposes of the law to encourage and support. ${ }^{18}$

If, however, the rationale for the requirement of actual defrauding or injury is, as was suggested, to diminish the scope of the crime of obtaining property under false pretenses, this qualitative-quantitative approach seems at least partially inconsistent with that rationale. It may be doubted, in addition, that. clarity in the criminal law is served by the Nelson court's approach.

and swindling ... [in overvaluing her security] would be in effect to imprison her for a debt. The State of Georgia was founded as a haven for those imprisoned for debt and it has been the policy of this state, from its inception to the present day, to oppose and discourage any action that savours of punishment for debt."

${ }^{17}$ People v. Smith, 5 Park. Crim. (N.Y.) 490, 515 (1863).

${ }^{18}$ Ibid., at 513. In Commonwealth v. Coleman, 60 Pa. Super. 512, 519 (1915) the court stated: "When he did the acts which the statute declares constitute that misdemeanor, he committed an offense against the sovereignty of the Commonwealth and could be properly indicted and punished therefor without regard to the state of the accounts between two private firms or corporations." See also the dissenting opinion in Commonwealth v. Harkins, 128 Mass. 79, 84 (1880).

\title{
CONFLICT-OF-LAWS PROBLEMS IN WORKMEN'S COMPENSATION: CARROLL V. LANZA
}

Speedy recoveries sought by the enactment of state workmen's compensation statutes have sometimes been impeded by problems arising from the workman's connection with more than one state. Often it is doubtful whether the state in which he first seeks recovery can grant either a compensation award or a common-law remedy. When the employee proceeds for workmen's compensation, determination by the tribunal that the compensation law of another state is applicable will frequently prevent compensation recovery in the forum since that state will usually have no administrative procedure for applying the foreign compensation statute. ${ }^{1}$ If the worker should attempt to

1 "Since there is usually no claim to be enforced unless the designated procedure has been followed, the right of workmen's compensation can generally be enforced only before the 
recover at common law, he may be barred by a provision in a foreign compensation statute to which full faith and credit must be given. The predicament of the injured workman is particularly unfortunate for he may be handicapped physically and financially in traveling to a foreign state. ${ }^{2}$

Two opposing principles have been applied in determining the effect to be given a foreign workmen's compensation statute. The earlier view, advanced in Bradford Electric Co. v. Clapper ${ }^{3}$ would strictly apply the full faith and credit clause to a foreign statute to deny a common-law recovery. ${ }^{4}$ Opposing this rigid application of the full faith and credit clause is the principle that any state which has a sufficient interest in the injured workman or in the

tribunal designated by the particular statute. If compensation is awarded in the manner prescribed, however, or if, as is the case in some jurisdictions, the procedure is not committed to a special administrative body, there is no obstacle to enforcing rights created under one act in the courts of another state. In spite of the difficulties inherent in the situation, five jurisdictions, by statute, expressly permit an employee hired outside those jurisdictions to enforce in their commissions or courts the rights acquired under the law of the state of hire." Conflict-of-Laws Provisions in Workmen's Compensation Acts, 57 Harv. L. Rev. 242 (1943).

2 See Alaska Packers Ass'n v. Industrial Accident Comm'n, 294 U.S. 532 (1935).

${ }^{3} 286$ U.S. 145 (1932). An action in tort was brought by an injured workman against his employer in a state court in New Hampshire, the state of the injury. The case was removed to the federal district court which granted the workman relief. The Circuit Court of Appeals affirmed, 51 F. 2d 992 (C.A. 1st, 1931), but on certiorari to the Supreme Court the decision was reversed. The employer pleaded as a defense the workmen's compensation statute of Vermont, the state of the employment contract. The Court held that New Hampshire was compelled to give full faith and credit to the Vermont statute which barred a common-law action against an employer covered by the statute.

'U.S. Const., Art. 4, $\$ 1$. "Full Faith and Credit shall be given in each State to the public Acts, Records, and Judicial Proceedings of every other State. And the Congress may by general Laws prescribed the Manner in which such Acts, Records and Proceedings shall be proved, and the Effect thereof."

On the relation of the full faith and credit clause to workmen's compensation statutes, consult generally: 2 Beale, Conflict of Laws $\$ \$ 398-403.1$ (1935); Goodrich, Conflict of Laws $\$ 100$ (3rd ed., 1949); Stumberg, Conflict of Laws 212-23 (2d ed., 1951) ; Leflar, Choice of Law: Torts: Current Trends, 6 Vand. L. Rev. 447 (1953) ; Cheatham, Federal Control of Conflicts of Law, 6 Vand. L. Rev. 581 (1953) ; Carnahan, What Is Happening in the Conflict of Laws: Three Supreme Court Cases, 6 Vand. L. Rev. 607 (1953); Reese, Full Faith and Credit to Statutes: The Defense of Public Policy, 19 U. of Chi. L. Rev. 339 (1952); Beale, Two Cases on Jurisdiction, 48 Harv. L. Rev. 620 (1935); Corwin, The "Full Faith and Credit" Clause, 81 U. of Pa. L. Rev. 371 (1933); 39 Col. L. Rev. 1024 (1939), noting Pacific Employers Insurance Co. v. Industrial Accident Comm'n, 306 U.S. 493 (1939); 46 Harv. L. Rev. 291 (1932), 42 Yale L. J. 115 (1932), both noting Bradford Electric Co. v. Clapper, 286 U.S. 145 (1931).

On the relation of a state's public policy to its right to deny full faith and credit to another state's law, consult generally: Jackson, Full Faith and Credit-The Lawyer's Clause of the Constitution, 45 Col. L. Rev. 1 (1945); Nussbaum, Public Policy and the Political Crisis in the Conflict of Laws, 49 Yale L. J. 1027 (1940); Goodrich, Foreign Facts and Local Fancies, 25 Va. L. Rev. 26 (1938); Nutting, Suggested Limitations of the Public Policy Doctrine, 19 Minn. L. Rev. 196 (1935); Lorenzen, Territoriality, Public Policy and 
employment relation can award him a compensation recovery despite provisions in foreign statutes which would appear to bar the remedy. During the past twenty-five years the interplay of these principles has been evidenced in a series of Supreme Court decisions which have demonstrated a decided trend toward the latter view. ${ }^{5}$ This trend reached its latest development in the recent case of Carroll v. Lanza. ${ }^{6}$

The Carroll case involved a construction workman who was severely injured while working on his job in Arkansas. A resident of Missouri, he was employed by a sub-contractor, also a resident of Missouri, under a Missouri employment contract. Immediately after the injury Carroll was removed to Missouri, and his employer's insurer began voluntary payments under the Missouri compensation act. After thirty-four weekly payments, Carroll stopped receiving Missouri compensation and applied for Arkansas compensation. Thereafter he brought a common-law tort action for negligence in an Arkansas court against the prime contractor Lanza, the Arkansas workmen's compensation statute not barring common-law actions against prime contractors. The case was removed to the federal district court because of diversity of citizenship and Lanza pleaded as a ground for dismissal the Missouri workmen's compensation statute which gave prime contractors immunity from common-law actions and argued that Arkansas must give full faith and credit to the Missouri statute. The lower courts found that Arkansas had a public policy in favor of allowing third party actions by employees. ${ }^{8}$ The Supreme Court held that Arkansas, because it was the state of injury, had such an interest in the injured workman that it was not required by the full faith

the Conflict of Laws, 33 Yale L. J. 736, 746 (1924); Beach, Uniform Interstate Enforcement of Vested Rights, 27 Yale L. J. 656 (1918) ; Public Policy and the Conflict of Laws, 7 Stanford L. Rev. 275 (1955); The Public Policy Concept in the Conflict of Laws, 33 Col. L. Rev. 508 (1933).

B Bradford Electric Co. v. Clapper, 286 U.S. 145 (1932); Ohio v. Chattanooga Boiler \& Tank Co., 289 U.S. 439 (1933); Alaska Packers Ass'n v. Industrial Accident Comm'n, 294 U.S. 532 (1935); Pacific Employers Insurance Co. v. Industrial Accident Comm'n, 306 U.S. 493 (1939) ; Cardillo v. Liberty Mutual Insurance Co., 330 U.S. 469 (1947); Carroll v. Lanza, 349 U.S. 408 (1955). See also Magnolia Petroleum Co. v. Hunt, 320 U.S. 430 (1943) ; Industrial Comm'n v. McCartin, 330 U.S. 622 (1947).

- 349 U.S. 408 (1955).

The application for Arkansas compensation appears clearly in the circuit court opinion, 216 F. 2 d 808 (C.A. 8th, 1954).

${ }^{8}$ The district court found an "established public policy in Arkansas favoring the common-law right of action for injuries to persons and property." Carroll v. Lanza, $116 \mathrm{~F}$. Supp. 491, 502 (1953). In support of the proposition the court cited Ark. Const. Art. V, $\$ 32$; Young v. G. L. Tarlton Contractor, Inc., 204 Ark. 283, 162 S.W. 2d 477 (1942); Anderson v. Sanderson \& Porter, 146 F. 2d 58 (1945) ; Magnolia Petroleum Co. v. Turner, 188 Ark. 177, 65 S.W. 2 d 1 (1933); Logan v. Missouri Valley Bridge \& Iron Co., 157 Ark. 528, 249 S.W. 21 (1923); Haynes Drilling Corp. v. Smith, 200 Ark. 1098, 143 S.W. 2d 27 (1940); and Smith v. Arkansas Power \& Light Co., 191 Ark. 389, 86 S.W. $2 d 411$ (1935). 
and credit clause to apply the Missouri statute and could, therefore, allow the action. $^{9}$

The opinion of the Court in the Carroll case makes little reference to the Clapper precedent ${ }^{10}$ though it seems clear that at the very least the Carroll decision threatens the validity of the Clapper analysis if it does not overrule Clapper. This comment will attempt to assess the present value of the Clapper doctrine confined, as it now must be, to the area of common-law actions against employers. Necessary, however, to such an evaluation is a preliminary

- The interest of Arkansas in the workman was reduced by Ark. Stat. Ann. \$ 81-1340 (Supp., 1956) which gave the immediate employer and the immediate employer's insurer a statutory lien on two-thirds of any recovery by the workman against a third party.

Justice Frankfurter, in dissent, suggested that the case be remanded to the circuit court to determine whether or not Lanza would actually receive immunity under Missouri law. "The rationale of the Missouri decisions prohibiting a negligence action against a prime contractor is this: a person clearly subject to statutory liability cannot be sued as a third party. ... Under the circumstances of the case before us, there is no basis for finding that Missouri would deem Lanza to be a Missouri employer and as such subject to liability for Missouri Workmen's Compensation." Carroll v. Lanza, 349 U.S. 408, 425 (1955). Such a " remand was, he thought, "a readily available alternative short of overruling Clapper which dispenses with the difficulties inherent in applying the Full Faith and Credit Clause." Ibid., at 422 .

${ }^{10}$ The majority's discussion was limited to the following: "A statute is a 'public act' within the meaning of the Full Faith and Credit Clause. See Bradford Electric Light Co. v. Clapper.... It was indeed held in the Clapper case that a Vermont Compensation Act, which purported to give an exclusive remedy, barred a common-law action on the same claim in the New Hampshire courts by a Vermont employee against a Vermont employer, even though the injury occurred in New Hampshire. The Clapper case allowed a State to fix one exclusive remedy for personal injuries involving its residents, and required the other States to refuse to enforce any inconsistent remedy. Thus, as respects persons residing or businesses located in a State, a remedy was provided employees that was 'both expeditious and independent of proof of fault,' and a liability was imposed on employers that was 'limited and determinate.' 286 U.S. at 159.

"Pacific Employers Insurance Co. v. Industrial Accident Commission . . . departed, however, from the Clapper decision." Carroll v. Lanza, 345 U.S. 408, 411 (1955).

The dissent written by Justice Frankfurter, however, indicated more clearly the conflict between Bradford Electric Co. v. Clapper, 286 U.S. 145 (1932) and the case at bar: "What might be regarded as the societal interest of Arkansas in the protection of the bodily safety of workers within its borders is an interest equally true of any jurisdiction where a workman is injured and exactly the sort of interest which New Hampshire had in Clapper. . . Thus, the Court is squarely faced with the Clapper problem. To make the interest of Arkansas prevail over the interest of Missouri on the basis of the Full Faith and Credit Clause would require that Clapper be explicitly overruled and that, in the area of workmen's compensation law, the place of injury be decisive. And if Clapper is to be overruled, on which I and those who join me express no opinion, it should be done with reasons making manifest why Mr. Justice Brandeis' long-matured, weighty opinion in that case was ill-founded. It should not be cast aside on the presupposition that full faith and credit need not be given to a sister-state workmen's compensation statute if the law of the forum happens to be more favorable to the claimant." Ibid., 420-22.

Note also that Justice Douglas, writing the majority opinion, gave as the reason for granting certiorari, "doubts as to the correctness of the decision [Carroll v. Lanza, $216 \mathrm{~F}$. 2d 808 (C.A. 8th, 1954)] raised by Pacific Employers Insurance Co. v. Industrial Accident Commission, 306 U.S. 493. ..." Tbid, at 410. 
survey of the conflict-of-laws problems presented by the workmen's compensation acts and the resolution of these problems to date. The pattern of fact situations giving rise to possible conflict-of-laws problems will be arranged in three basic categories-proceedings for workmen's compensation, commonlaw actions against employers, and common-law actions against third parties. Against this background, the validity of the Clapper precedent will be examined in the fourth section.

\section{I}

In a proceeding for workmen's compensation, recovery may turn upon whether the forum is the state of contract or the state of injury. ${ }^{11}$ Where the forum is the state of contract, preliminary to any conflict-of-laws problem is the question whether or not the forum's worlmen's compensation statute should be construed as applying to out-of-state injuries. There are three principal theories of construction if the statute has no express provision. ${ }^{\mathbf{1 2}}$ Under the "tort" theory, the state of contract cannot give compensation if the injury occurs in another state, but under the "contract" and "statutory-relation" theories compensation is available.

Under the tort theory, the workmen's compensation statute is approached as a substitute for the employer's tort liability. ${ }^{13}$ If the statute is ambiguous as to whether or not foreign injuries are covered, the court will apply the rule that the law of the place of injury governs, ${ }^{14}$ and recovery under the local statute will be denied. ${ }^{15}$ Not only is this a mechanical solution, ${ }^{16}$ but it also

\footnotetext{
${ }^{11}$ In general this comment will be confined to situations where the proceeding for workmen's compensation or a common-law tort action is brought either in the state of contract or in the state of injury. Analogous problems will arise in the less frequent situation where the action is brought in a third state.

12 The three principal theories-tort, contract, and statutory-relation-are discussed in Dwan, Workmen's Compensation and the Conflict of Laws-The Restatement and Other Recent Developments, 20 Minn. L. Rev. 19 (1935); Dunlap, The Conflict of Laws and Workmen's Compensation, 23 Cal. L. Rev. 381 (1935); Dwan, Workmen's Compensation and the Conflict of Laws, 11 Minn. L. Rev. 329 (1927); Extraterritorial Operation of Workmen's Compensation Statutes, 3 A.L.R. 1351 (1919) supplemented at 18 A.L.R. 292 (1922) ; 28 A.L.R. 1345 (1924); 35 A.L.R. 1414 (1925) ; 45 A.L.R. 1234 (1926) ; 59 A.L.R. 735 (1929); 82 A.L.R. 709 (1933); 90 A.L.R. 119 (1934).

${ }^{13}$ See Gould's Case, 215 Mass. 480, 102 N.E. 693 (1913).

"Rest., Conflict of Laws, $\$ \$ 377-79$ (1934).

${ }^{15}$ After Gould's Case, 215 Mass. 480, 102 N.E. 693 (1913), Massachusetts rejected the tort theory by amending its workmen's compensation statute to cover specifically out-ofstate injuries. Mass. Act (1927) c. $309, \S 3$, as amended, Mass. L. Ann. (Recompilation, 1949) c. $152, \S 26$. Illinois and California also initially adopted the tort theory. Union Bridge Co. v. Industrial Comm'n, 287 Ill. 396, 122 N.E. 609 (1919) ; North Alaska Salmon Co. v. Pillsbury, 174 Cal. 1, 162 Pac. 93 (1916). But their statutes were also amended to cover out-of-state injuries. Cal. Stat. (1915) c. 607, $\$ 26$, superseded by Cal. Stat. (1917) c. 586, $\$ 58$, as amended, Cal. Labor Code Ann. (Deering, 1953) § 5305; IIl. L. (1925) p. 380 , § 5, superseded by Ill. L. (1951) p. 1061, as amended, MI. Rev. Stat. (1955) c. 48, $\$ 138.1(\mathrm{~b})(2)$. Oklahoma appears to be the only state which still will not give a compensa-
} 
may deprive a workman of any compensation award for an otherwise compensable injury. ${ }^{17}$

Under the contract theory, the limitations of the tort theory are avoided by reasoning that the workmen's compensation act of the state of the employment contract becomes a part of that contract. Thus, while remaining faithful to another choice-of-law rule--that the place of contract governs actions arising under the contract ${ }^{18}$ - the forum can allow recovery for out-of-state injuries under its own law. ${ }^{19}$ This theory is open to criticism as it is a fiction to call the liability of the employer contractual. Rather, the liability is imposed by statute. ${ }^{20}$ Where the act is compulsory, that is, where the parties cannot contract out of the liability imposed by the act, no mutual assent whatsoever exists. Even where the act is elective, the employer is for practical reasons forced to come under the act; if he does not so submit, typically the common-law fellow-servant and assumption-of-risk defenses are taken away. ${ }^{21}$

tion award for injuries occurring out-of-state. Battiest v. State Industrial Comm'n, 197 Okla. 618, 173 P. 2d 922 (1946); Continental Oil Co. v. Pitts, 158 Okla. 200, 13 P. 2d 180 (1932); see Tri-State Casualty Ins. Co. v. Stekoll, 201 Okla. 548, 208 P. 2d 545 (1949); Utley v. Industrial Comm'n, 176 OkJa. 255, 55 P. 2d 762 (1936).

${ }^{18}$ The New York statute illustrates the non-tortious aspects of the liability: "Every employer subject to this chapter shall in accordance with this chapter . . . secure compensation to his employees and pay or provide compensation for their disability or death from injury arising out of and in the course of the employment without regard to fault as a cause of the injury, except that there shall be no liability for compensation under this chapter when the injury has been solely occasioned by intoxication of the injured employee while on duty or by wilful intention of the injured employee to bring about the injury or death of himself or another." N.Y. Workmen's Compensation Law (McKinney Supp., 1955) $\$ 10$.

${ }^{17}$ Consult note 19 infra. $\quad{ }^{18}$ Rest., Conflict of Laws $\$ 332$ (1934).

${ }^{10}$ The adoption of the contract theory in preference to the tort theory probably resulted because, under a system where only a few states had compensation acts, if the state of contract gave no award, compensation would not be available elsewhere. However, even when all states have compensation acts, the policy of workmen's compensation giving the workman a sure, quick recovery demands that the state of contract be able to give compensation. Otherwise, "Both the employer and the employee would be relegated to the uncertain rights and liabilities of the common-law tort action or to the equally uncertain remedy of the workmen's compensation act of some sister state of whose provisions they had no knowledge and with which they had made no attempt to comply. The result might be a situation that would be more uncertain and less satisfactory to employer and employee than that which prevailed before the adoption of the workmen's compensation acts. . ." Val Blatz Brewing Co. v. Industrial Comm'n, 201 Wis. 474, 479, 230 N.W. 622,624 (1930).

${ }^{20}$ The contract theory is most often adopted by states having a so-called elective type act wherein the act applies unless in the employment contract the parties specifically provide that it shall not apply. See State ex rel. Chambers v. District Court, 139 Minn. 205, 166 N.W. 185 (1918). With such a statute there is some reality in saying that the act becomes part of the contract. However, the contract theory has also been applied in states where the workmen's compensation act is compulsory. See Beall Bros. Supply Co. v. Industrial Comm'n, 341 IIl. 193, 173 N.E. 64 (1930); here the rationale of the contract theory is more obscure.

${ }^{21}$ E.g., Alabama Code (1940) c. $26, \S \S 254,255$; here the statute further provides that the employer electing not to come under the Act is liable even though the employee is guilty of willful misconduct. 
Further, contractual obligations are subject to modification by assent of the parties, but the obligations under the statute can be modified only by the legislature. ${ }^{22}$

Under the third approach, the statutory-relation theory, liability is neither tortious nor contractual, but is imposed by law on the employment relationship. The liability arises by statute and operates by attaching to the status of employment certain rights and obligations. ${ }^{23}$ This status continues as modified even though the employee goes out of the state. If he is injured outside the state of contract, that state can then award compensation. The statutoryrelation theory is more realistic than the tort or contract theories; the initial judicial hesitance to adopt it probably stemmed from a desire to fit workmen's compensation cases within existing tort and contract choice-of-law rules. $^{24}$

Assuming, as is the general rule, that the contract state will construe its compensation statute as applicable to out-of-state injuries, its constitutional power to do so was doubted until Alaska Packers Ass'n v. Industrial Accident Comm'n. ${ }^{25}$ The problem in that case was whether or not the rigid application of the full faith and credit clause required by Bradford Electric Co. v. Clapper ${ }^{26}$-a case involving a common-law action in the state of injury- should be carried over into the area of compensation proceedings. In the Alaska Packers case, though the employment contract was made in California, all of the work was to be done in Alaska. Furthermore, the contract provided that Alaska's compensation act should apply exclusively. The Supreme Court held that California could award compensation under its statute though the injury occurred in Alaska. Even though both acts purported to give the exclusive remedy, the Court rejected the argument that the full faith and credit clause required California to defer to the Alaska act because California had a sufficient interest in the employment status to provide compensation. ${ }^{27}$

${ }^{22}$ See Anderson v. Miller Scrap Iron Co., 169 Wis. 106, 114, 170 N.W. 275, 277 (1919).

See Val Blatz Brewing Co. v. Industrial Comm'n, 201 Wis. 474, 478, 230 N.W. 622, 624 (1930).

${ }^{25}$ These traditional rules are not absolute doctrines that are uniformly followed. For an analysis of the diversity of decisions in the tort area, consult Rheinstein, The Place of Wrong: A Study in the Method of Case Law, 19 Tulane L. Rev. 4, 165 (1944).

25294 U.S. 532 (1935).

${ }^{20} 286$ U.S. 145 (1932). Following this decision, it was assumed that the state of injury could not award compensation when the state of contract had a statute which purported to give an exclusive remedy. Consult, e.g., Bradford Electric Co. v. Clapper: Full Faith and Credit and the Workmen's Compensation Statutes, 46 Harv. L. Rev. 291, 296-97 (1932).

27 The employee had been transported to Alaska by the employer at the beginning of the term of employment and had been transported back at the conclusion. California had no administrative procedure for applying the Alaska act, and to force the injured worker to return to Alaska to pursue his remedy would impose an impossible requirement on him. As a practical matter, if California were forced to deny compensation, no compensation would be available to the employee. The case represents a careful weighing of the interests 
When the proceeding for workmen's compensation is brought in the state of injury, ${ }^{28}$ a strict interpretation of the full faith and credit clause would preclude a compensation award. ${ }^{29}$ However, in Pacific Employers Insurance Co. v. Industrial Accident Comm'n, ${ }^{30}$ the Supreme Court held that California might award workmen's compensation under its act where the injury occurred in California even though Massachusetts was the state where the employment contract was made and where the bulk of the employment was carried out. The California court had articulated a decided public policy of giving compensation to workmen injured in the state, which policy would be frustrated by application of the Massachusetts statute. ${ }^{31}$ The existence of this policy ${ }^{32}$ raised the issue whether or not California had, in view of the full faith and credit clause, a sufficient interest to refuse to apply the Massachusetts statute. Though the decision has been generally accepted ${ }^{33}$ as establishing the principle that the state of injury will always have a sufficient interest to award compensation, ${ }^{34}$ in fact the opinion represents a careful evaluation of specific factors. Unpaid California medical bills and the burden of an impoverished, injured workman upon the state were stressed by the Court.

Occasionally an employee will bring a proceeding for workmen's compensation in a state other than the state of injury or the state of contract. In this third-state situation two questions arise. First, under what circumstances will the state apply its compensation statute, and second, assuming it will, when can it constitutionally do so? As to the first question, normally a non-

of the two jurisdictions. Compare the less flexible approach of Carroll v. Lanza, 349 U.S. 408 (1955).

${ }^{28}$ The workmen's compensation statutes have generally been construed or are in terms applicable to injuries occurring within the state. There is not, therefore, the preliminary statutory-construction problem that is present where the compensation proceeding is brought in the state of contract on an injury occurring outside that state.

${ }^{2}$ Cf. Bradford Electric Co. v. Clapper, 286 U.S. 145 (1932).

${ }^{30} 306$ U.S. 493 ((1939).

${ }^{3 t}$ Note that seldom will the forum be able to apply a foreign workmen's compensation statute because the statutes provide for administrative procedures which will be difficult to follow in another state. See note 1 supra.

${ }^{32}$ On this ground, Bradford Electric Co. v. Clapper, 286 U.S. 145 (1932) was distinguished for, "[t]here was nothing in the New Hampshire statute, the decisions of its courts, or in the circumstances of the case, to suggest that reliance on the provisions of the Vermont statute, as a defense to the New Hampshire suit, was obnoxious to the policy of New Hampshire." Pacific Employers Insurance Co. v. Industrial Accident Comm'n, 306 U.S. 493, 504 (1939). Consult text discussion of Bradford Electric Co. v. Clapper, infra at p. 524, and Mr. Justice Stone's concurring opinion in that case, 286 U.S. 145, 163 (1932).

${ }^{3 s}$ See e.g., Jonathan Woodner Co. v. Mather, 210 F. 2 d 868 (App. D.C., 1954) ; People v. Chicago Lloyds, 391 Ill. 492, 63 N.E. 2d 479 (1945).

${ }^{34}$ If the case is accepted as creating no exceptions to the power of the state of injury to. apply its own compensation act, it is the basis for a rule as inflexible as that of Bradford Electric Co. v. Clapper, 286 U.S. 145 (1932). 
contract, non-injury state will not award compensation, but some states will if the employment relation exists on a permanent basis within the forum. ${ }^{\mathbf{3 5}}$ The Supreme Court has never faced the second problem nor has it ever said, as seems clear, that the above test is constitutionally appropriate. Therefore, the problem of the minimal contacts with the employment relation necessary for a non-contract, non-injury state constitutionally to award compensation has not been squarely raised. However, in Cardillo v. Liberty Mutual Insurance $\mathrm{Co}^{36}$ the Supreme Court affirmed a District of Columbia workmen's compensation award on the basis that the existence of a substantial connection between the District and the particular employee-employer relationship had established a "legitimate interest"37 in the District. Since the Court did not appear to attach any significance to the making of the employment contract within the District, it can be inferred that the Court would have held similarly had the contract been made outside the District.

\section{II}

Since all states have now passed workmen's compensation statutes, the incidence of common-law actions against employers has been greatly reduced. Problems in the area of conflict-of-laws are now restricted to situations where for one reason or another ${ }^{38}$ the statute is applicable to the employer in one

35 McKesson-Fuller-Morrison Co. v. Industrial Comm'n, 212 Wis. 507, 250 N.W. 396 (1933) ; Etters v. Trailways of New England, Inc., 266 App. Div. 929, 43 N.Y.S. 2d 884 (3d Dep't, 1942) (semble). This existence-of-the-relation test, if adopted at all, will generally be the sole test of the applicability of the compensation statute and thus will have a much broader application than the narrow situation suggested in the text. E.g., Hawco v. Williams Neill Constructors, Inc., 275 App. Div. 878, 88 N.Y.S. 2d 640 (3d Dep't, 1949); Interstate Power Co. v. Industrial Comm'n, 203 Wis. 466, 234 N.W. 889 (1931). Note that as a matter of statutory construction under this test, the place of contract formation and the place of injury are immaterial.

As the constitutional requirement of sufficient interest is directed more to the connection of the state with the employment relation than with the fortuitous location of contract formation or injury, this existence-of-the-relation test has the virtue of being parallel to the constitutional requirement.

A closely related test is the "localization of employer's business" test adopted in Minnesota. See Severson v. Hanford Tri-State Airlines, Inc., 105 F. 2d 622 (C.A. 8th, 1939), where the court held that the Minnesota compensation statute acted as a bar to a Minnesota common-law action where injury occurred in Wisconsin and the employment contract was made in Iowa.

${ }^{36} 330$ U.S. 469 (1947).

${ }^{37}$ Ibid., at 476.

${ }^{28}$ Though both statutes are exclusive one may be applicable where the other is not because: (1) the employer does not have a sufficient number of employees within one state; (2) the employer may have failed to comply with some specific requirement of one state's statute; (3) the injury may be within one but not within another state's definition of compensable injuries; (4) the employment contract may have specifically excepted compensation coverage and this exception is valid only under one state's elective-type statute; or (5) one state's statute may give the employee a post-injury option of applying for workmen's compensation or bringing a common-law action. Consult 2 Larson, Workmen's Compensation $\$ 67.21$ (1952). Generally speaking, if compensation is not available the 
state but not in another.

In the leading case of Bradford Electric Co. v. Clapper, ${ }^{39}$ the employee elected to sue his employer at common law in New Hampshire under a statute providing workmen with a post-injury option to bring either a common-law action or a compensation proceeding. New Hampshire was the state of injury whose tort law, under traditional choice-of-law rules, was applicable. The action was brought originally in the New Hampshire court but removed to federal court. The lower courts granted relief, but the Supreme Court reversed, holding that the compensation act of Vermont, the state of contract, was entitled to full faith and credit, and since it purported to provide the exclusive remedy, ${ }^{40}$ it acted to bar the common-law action in New Hampshire.

Although the Court appeared to base its holding on the ground that refusal to give effect to a substantive defense arising under the law of another state would subject the defendant to irremediable liability, ${ }^{41}$ the Court went on to observe that no New Hampshire precedent existed holding application of a foreign compensation act contrary to local public policy. ${ }^{42}$ In this manner, the Court hedged its holding by leaving open the question of what its decision would have been had such a New Hampshire precedent existed or had the case not been removed from the New Hampshire state court. This ambiguity in the majority holding was pointed up by the concurring opinion of Justice Stone. He questioned whether the full faith and credit clause should ever be applied to deny a recovery in such a case; however, in the absence of a controlling New Hampshire opinion, he was willing to assume that the New Hampshire courts would recognize the Vermont statute as a matter of comity. ${ }^{43}$

employee can bring an action at common law although, of course, there is no assurance that he will recover.

2986 U.S. 145 (1932).

${ }^{40}$ Cf. Ohio v. Chattanooga Boiler \& Tank Co., 289 U.S. 439 (1933).

41 "A State may, on occasion, decline to enforce a foreign cause of action. In so doing, it merely denies a remedy, leaving unimpaired the plaintiff's substantive right, so that he is free to enforce it elsewhere. But to refuse to give effect to a substantive defense under the applicable law of another State ... subjects the defendant to irremediable liability. This may not be done." Bradford Electric Co. v. Clapper, 286 U.S. 145, 160 (1932).

42 Cf. Pacific Employers Insurance Co. v. Industrial Accident Comm'n, 306 U.S. 493 (1939), where the highest court of California had an opportunity to declare a public policy. Consult text supra at p. 522 .

4 "I should hesitate to say that the Constitution projects the authority of the Vermont statute across state lines into New Hampshire, so that the New Hampshire courts, in fixing the liability of the employer for a tortious act committed within the state, are compelled to apply Vermont law instead of their own." Bradford Electric Co. v. Clapper, 286 U.S. 145, 163 (1932). Mr. Justice Stone later wrote the opinions in Alaska Packers Ass'n v. Industrial Accident Comm'n, 294 U.S. 532 (1935) and Pacific Employers Insurance Co. v. Industrial Accident Comm'n, 306 U.S. 493 (1939) which substantially departed from the broad Clapper doctrine of requiring full faith and credit to foreign compensation acts. 
Had the occasion arisen, the Clapper precedent would presumably have been strictly applied in cases of employee-employer common-law actions brought in the state of injury. ${ }^{44}$ Where the action is brought in the state of contract it has been said that, "[i]n an employee-employer suit, if some workmen's compensation act purports to bar the action, that bar will be applied in the forum. $\$ 45$

The problem where the common-law action is brought in the state of contract is not, at least since Carroll v. Lanza, as simple as the quotation would indicate. Where the state of contract would allow the action but the state of injury would not, normal choice-of-law rules would deny relief ${ }^{46}$ However, the Alaska Packers case, if a compensation case is a precedent for a commonlaw action, would indicate that the forum, if it had a sufficient interest, could constitutionally disregard normal choice-of-law rules to grant relief based on its own law. Carroll v. Lanza did not hold or clearly imply that the mere formation of the employment contract within the state gives that state a sufficient interest to refuse to apply the injury-state statute. The Carroll case narrowly held that the fact of injury within a state would give that state a sufficient interest in the workman or the employment relation to apply its

4 Cf. Ohlaver v. Narcon, 195 F. 2d 676 (C.A. 4th, 1952) ; Biddy v. Bluebird Air Service, 374 III. 506, 30 N.E. 2d 14 (1940) ; Personius v. Asbury Transportation Co., 152 Ore. 286, 53 P. 2d 1065 (1936) (all third party actions). Conceivably if the action were brought in the state of injury which gave the employer immunity from common-law actions, but the state of contract did not, it could be argued on the basis of Bradford Electric Co. v. Clapper, 286 U.S. 145 (1932), that the law of the state of contract must constitutionally control the issue of the employer's immunity from common-law action and, therefore, the action should be allowed. This position ignores the "irremediable liability" language of Bradford Electric Co. v. Clapper, supra, since application of the foreign law in this situation would impose a liability which would be denied under the law of the forum. Also it should be noted that the foreign right of action will not generally be based on a statute, thus creating additional problems for application of the full faith and credit clause. This was the situation in Scott v. White Eagle Oil \& Refining Co., 47 F. 2d 615 (D.C. Kan., 1930) and Barnhardt v. American Concrete Steel Co., 227 N.Y. 551, 125 N.E. 675 (1920) but the problem suggested was not raised or discussed by the court. Cf., Bagnel v. Springfield Sand \& Tile Co., 144 F. 2d 65 (C.A. 1st, 1944) (third party action).

${ }^{15}$ Jonathan Woodner Co. v. Mather, 210 F. $2 d$ 868, 873 (App. D.C., 1954).

${ }^{28}$ Tbid.; Mitchell v. J. A. Tobin Construction Co., 236 Mo. App. 910, 159 S.W. 2d 709 (1942). Cf. Christ v. Chicago \& N.W. Ry. Co., 176 Minn. 592, 224 N.W. 247 (1929) (not clear that forum was the state of contract). Yoshi Ogino v. Black, 304 N.Y. 872, 109 N.E. $2 \mathrm{~d} 882(1952)$ is an extreme example. There the employee brought a common-law action against his employer in New York (apparently the state of contract) on an injury incurred in North Carolina. The defense was that the compensation act of the state of injury barred the action. Previously the plaintiff's application for New York compensation had been rejected on the grounds that the injury did not arise "out of or in the scope of employment." The court held the action barred by the North Carolina compensation act; the New York Board's finding that the plaintiff's injury was a non-employment injury would not be res judicata on the North Carolina Board. Thus, although it was quite likely the plaintiff would not be able to get workmen's compensation anywhere, the New York court denied a common-law recovery. Compare Alaska Packers Ass'n v. Industrial Accident Comm'n, 294 U.S. 532 (1935). 
own law without regard to the compensation statute of any other state. ${ }^{47} \mathrm{But}$ in its reliance on Pacific Employers the Court stated that the distinction between compensation proceedings and common-law actions was not "a material difference"48 for purposes of determining whether or not the full faith and credit clause required application of another state's statute. ${ }^{49}$ This language would indicate that the contract state could constitutionally grant a commonlaw recovery despite the compensation statute of the injury state. The reasoning of the Court in Carroll would appear to support this conclusion. The decision in Carroll may well have been based on the belief that more often than not the workman receives medical attention at the situs of his injury and may frequently be unable to travel after the accident. 50 The same type of "on-thewhole" approach would lead to the conclusion that the state of contract would also have a sufficient interest since it is generally the residence of the workman and also the place where the bulk of the employment is carried out.

The problem in the converse of the above situation-where the action is brought in the state of contract which would deny a common-law action whereas the state of injury would allow an action ${ }^{51}$-is identical to the problem above except that the forum's law is being applied contrary to normal choice-of-law rules in order to deny rather than to allow the action, ${ }^{52}$ The language of the Court's opinions in this field would indicate that this is not an

${ }^{47}$ Consult note 61 infra.

${ }^{48}$ Carroll v. Lanza, 349 U.S. 408, 412 (1955).

${ }^{4} \mathrm{~A}$ possible justification for a difference in result between common-law and compensation actions is that when the forum gives a compensation award, the employee cannot go to another state and recover any more than the maximum available in either state, MCCartin v. Industrial Comm'n, 330 U.S. 622 (1947) ; but cf. Magnolia Petroleum Co. v. Hunt, 320 U.S. 430 (1943); that is, there is no double recovery. But if a common-law recovery is allowed, the employee may recover much more than any possible compensation award and yet the employer has no absolute assurance that he will not be liable for a compensation award in another state. Cf. Betts v. Southern Ry. Co., 71 F. 2d 787 (C.A. 4th, 1934); Personius v. Asbury Transportation Co., 152 Ore. 286, 53 P. 2d 1065 (1936). However, the doctrine of election-of-remedies usually prevents double recovery. Consult 2 Larson, Workmen's Compensation Law $\$ \$ 73.00-73.30$ (1952).

5o "The State where the tort occurs certainly has a concern in the problems following in the wake of the injury. The problems of medical care and of possible dependents are among these. ..." Carroll v. Lanza, 349 U.S. 408, 413 (1955).

5 This situation was before the court in Anderson v. Miller Scrap Iron Co., 169 Wis. 106,170 N.W. 275 (1919); the court concluded that the law of the forum was applicable to deny the common-law action. But cf. Foster v. Denny Motor Transfer Co., 100 F. 2d 658 (C.A. 7th, 1938) (third party action arriving at the opposite result).

52 The two problems differ insofar as the first involves the applicability of the full faith and credit clause to an immunity provision of the injury-state's workmen's compensation statute; in the second situation full faith and credit could only be given to a negative inference from the injury-state's statute. That is, in the latter situation, normal choice-oflaw rules would refer to the general tort law of the state of injury; the only way in which full faith and credit could arguably be required to be given the injury-state's statute would be by assuming the failure to immunize the employer indicated a statutory policy of allowing common-law actions. This argument is somewhat strained in an employee-employer action for, as indicated in note 38 supra, an injury-state's law would normally bar an em- 
important distinction, ${ }^{53}$ but it is also true that Pacific Employers, Alaska Packers and Carroll all allowed application of the forum's law to grant relief. There is something of a difference between saying that a state has a sufficient interest in the employment relation to grant a remedy and saying that a state has a sufficient interest to deny a remedy, although it is difficult to see any rational basis for a different standard in the two situations. The interest which the forum would be protecting by denying a common-law action would be the employer's; such a decision could be justified on the policy of the compensation statutes that the employer's liability should be determinate. Furthermore, by denying a common-law action because of its workmen's compensation statute, the forum is not saying that the workman has no remedy in the forum, but rather that his remedy is by way of compensation. So phrased it seems unlikely that the Court would attempt to distinguish the forum's interest adequate to award recovery from the interest adequate to deny recovery contrary to an applicable foreign law.

\section{III}

In a case of an employee common-law action against a person other than his employer the applicable compensation statute may give immunity from

ployee-employer common-law action unless the statute was simply inapplicable. However, in employee-third party actions the argument is more cogent for, although the statute may be applicable, it may not give immunity to this particular class of third parties. Consult notes 54 and 56 infra. Note, however, that the power of a state to disregard traditional choice-of-law rules may be limited not only by the full faith and credit clause but also by the due process clause of the Fourteenth Amendment. Consult Overton, State Decisions in Conflict of Laws and Review by the United States Supreme Court under the DueProcess Clause, 22 Ore. L. Rev. 109 (1943); O'Meara, Constitutional Aspects of the Conflict of Laws: Recent Developments, 27 Minn. L. Rev. 500 (1943) ; Hilpert and Cooley, The Federal Constitution and the Choice of Law, 25 Wash. U.L.Q. 27, 46-59 (1939); Dodd, The Power of the Supreme Court To Review State Decisons in the Field of Conflict of Laws, 39 Harv. L. Rev. 533, 548-62 (1926). Normally the issue of due process is not reached for the full faith and credit clause provides a more meaningful analysis. However, in the international area, the full faith and credit clause is not operative and therefore due process is an effective limitation of choice of law. See Lauritzen v. Larsen, 345 U.S. 571 (1953), which involved a proceeding begun in a New York court under the Jones Act by an injured seaman who had entered into a contract of employment in New York and was injured in the territorial waters of Cuba. The ship and seaman were Danish. Although the decision held only that the Jones Act did not provide relief as a matter of statutory construction, the opinion indicates the Court so held because application of local law would be a violation of due process. But cf. The Fletero v. Arias, 206 F. 2 d 267 (C.A. 4th, 1953); Samad v. Etivebank, 134 F. Supp. 530 (E.D. Va., 1955). For examples of due process as a limitation on choice of law between states consult Home Insurance Co. v. Dick, 281 U.S. 397 (1930) ; Hartford Accident \& Indemnity Co. v. Delta \& Pine Land Co., 292 U.S. 143 (1934).

${ }^{5}$ But see Justice Frankfurter's statement, "It [Justice Brandeis' opinion in Bradford Electric Co. v. Clapper, 286 U.S. 145 (1932)] should not be cast aside on the presupposition that full faith and credit need not be given to a sister-state workmen's compensation statute if the law of the forum happens to be more favorable to the claimant." Carroll v. Lanza, 349 U.S. 408,422 (1955). 
suit to the third party. ${ }^{54}$ However, some statutes give no immunity ${ }^{55}$ and others give immunity only to particular classes of third parties. ${ }^{56}$ Where the common-law action is brought in the state of injury, and the forum's compensation act gives immunity to the third-party defendants-assuming the forum's compensation statute is applicable-the action clearly will be barred. ${ }^{57}$

Where the statute of the forum, the state of injury, gives no immunity, ${ }^{58}$ but the statute of the state of contract does give immunity, the court must decide which law controls to determine whether the common-law action will be barred. In Stacey v. Greenberg, ${ }^{59}$ the plaintiffs were injured while driving through New Jersey, the state of the forum, en route to New York from an employment assignment in Pennsylvania. The forum's statute gave no thirdparty immunity, but New York, the state of contract, did give immunity. The New Jersey Supreme Court dismissed the action. They reasoned that since the forum's compensation act did not apply as a matter of statutory construction, ${ }^{60}$ only the New York compensation act was applicable; since under the latter act the plaintiffs had given up their rights against third parties, the action could not be maintained in New Jersey. On this analysis the court avoided the issue of whether or not New Jersey was compelled, by reason of the full faith and credit clause, to apply the contract-state's compensation statute.

Assume, however, the New Jersey Supreme Court had allowed the action and the defendant had appealed to the United States Supreme Court and on the authority of the Clapper case alleged a violation of the full faith and credit clause. This is precisely what happened in Carroll v. Lanza. The Court in the Carroll case appeared to hold that the mere fact of injury gave the forum a sufficient interest to allow a common-law action against a third party. ${ }^{61}$ Thus, under the Carroll rule, the Stacey court constitutionally could

${ }^{54}$ E.g., Wash. Rev. Code (1951) § 51.24.010.

${ }^{5}$ E.g., 77 Pa. Stat. Ann. (Purdon's, 1952) $\S 1$ et seq.

${ }^{56}$ E.g., N.Y. Workmen's Compensation Law (McKinney, 1946) $\$ 29(6)$ which immunizes everyone in the "same employ" as the injured workman.

${ }^{57}$ This would be clear where the contract-state also gave immunity. Where it did not, the situation is directly parallel to that discussed in note 44 supra.

${ }^{58}$ The state of injury may give no third-party immunity either because its statute has no provision for immunity or because its statute is inapplicable because, for example, the employer has fewer employees in the state than the minimum required for application of the statute. Consult note 38 supra.

E9 9 N.J. 390, 88 A. 2 d 619 (1952).

${ }^{\infty}$ The New Jersey court held the statute inapplicable because "Their [the plaintiffs'] contact with our State was purely casual and not in the performance of their employment contracts within the reach of our decisions which imply our statute into a foreign contract of hiring to be performed in this State." Ibid., at 397 and 622.

${ }^{\text {ex }}$ Carroll v. Lanza, 349 U.S. 408 (1955), was itself a rather extreme case as the injured workman was removed from Arkansas, the state of injury, immediately after the accident and never returned. Thus the possibility of unpaid medical bills and the workman becoming 
have allowed the third-party action.

The problems presented where the action is brought against the employer in the state of contract are identical to those which would be presented were the common-law action brought against a third party rather than the employer. Alaska Packers combined with Carroll v. Lanza indicate that the contract state constitutionally could apply its own law in disregard of the statute of the state of injury regardless of whether the result was to grant or to deny the action. ${ }^{62}$

The discussion thus far has largely assumed the validity of the Clapper doctrine, at least in its own area. The question remains: is the Clapper case still law insofar as it holds that a workmen's compensation statute of the state of contract purporting to give an exclusive remedy must be given full faith and credit, thereby barring a common-law action against the employer in the state of injury?

To the extent that the Clapper case required rigid application of the full faith and credit clause, that rule is generally considered to have been narrowed by the Pacific Employers case which held that in compensation proceedings the state of injury need not be a vassal to the contract-state but may apply its own law. But, when the Carroll case arose, the defendant employer, relying on Clapper, argued that the Pacific Employers case could be distinguished on two levels.

First, Pacific Employers left some doubt that injury without any other contact with the employment relation was sufficient to give a state the unrestricted power to apply its own law regardless of a defense based on the statute of any other state. ${ }^{63}$ Unlike the Pacific Employers fact situation, the workman in Carroll was immediately removed to a hospital in the contract-state where he remained until physically recovered. However, the Court in the

a charge on the state could not be a basis for establishing the forum's interest. Compare Pacific Employers Insurance Co. v. Industrial Accident Comm'n, 306 U.S. 493 (1939). That the Carroll decision was intended to establish a general rule is further indicated by Justice Douglas' statement that "we write not for this case and day alone, but for this type of case." Carroll v. Lanza, 349 U.S. 408, 413 (1955).

${ }^{62}$ Consult text at 526 and notes 52 and 53 supra.

The Court in Pacific Employers Insurance Co. v. Industrial Accident Comm'n, 306 U.S. 493 (1939) emphasized certain factual aspects of the case which gave the injury-state power to make the award, e.g., local unpaid medical bills. The state and lower courts have generally assumed that there is no limitation on the state of injury in compensation cases after Pacific Employers Insurance Co. v. Industrial Accident Comm'n, supra. Consult authorities cited note 33 supra. Certainly after the Court's broad affirmation of the legitimacy of the injury-state's interest in Carroll v. Lanza, 349 U.S. 408 (1955), there can be little question that injury alone is a sufficient basis for the award of workmen's compensation as well as a common-law remedy against third parties. 
Carroll case was not interested in minute factual distinctions but rather was determined to establish a definite rule for "we write not only for this case and this day alone, but for this type of case."64 The "societal interest" of the state in the problems which follow all such local injuries is the basis of the state's power to refuse to apply another state's statute. On the level of the state's interest, the three classes of remedies-that is, the compensation proceeding, the employee-employer tort action, and the employee-third party tort action-are indistinguishable. ${ }^{66}$

Second, the defendant in Carroll argued that Pacific Employers was distinguishable, the latter being a compensation proceeding and the case at bar a common-law tort action. Superficially this distinction is plausible for the compensation act, particularly when it purports to give an exclusive remedy, represents an enunciated policy which is opposed to application of full faith and credit; the tort action is, however, a common-law remedy and is by its very nature silent as to any policy concerning full faith and credit. ${ }^{67}$ But this distinction is on the level of enunciated policy; $;^{68}$ the underlying interest of the state is identical whether the action is for compensation or at commonlaw. The majority in Carroll explicitly stated that the distinction between compensation proceedings and common-law actions was not "a material difference."

Thus, the interest of a state sufficient to deny full faith and credit arises independently of the type of action involved; only the relation of the state

" Carroll v. Lanza, 349 U.S. 408, 413 (1955).

es "Societal interest" is the term used by Justice Frankfurter in his dissent in Carroll v. Lanza. Ibid., at 421.

${ }^{8 B}$ Not only does Carroll v. Lanza, 349 U.S. 408 (1955) indicate that these classes of remedies are indistinguishable, but if, as the opinion suggests, the distinction between a compensation proceeding and a third-party tort action is not a "material difference" (ibid., at 412), then a fortiori there is not a material difference between compensation proceedings and employee-employer common-law actions. Thus Carroll v. Lanza, supra, may stand simply for judicial recognition of the fact that Pacific Employers Insurance Co. v. Industrial Accident Comm'n, 306 U.S. 493 (1939), overruled Bradford Electric Co. v. Clapper, 286 U.S. 145 (1932).

${ }^{67}$ A workmen's compensation statute that does not provide immunity for third parties expresses no policy on the issue of whether or not another state's statute shall be given full faith and credit. Rather it merely expresses a policy that in the local state the compensation statute shall not be a defense in a tort action by an employee against a third party.

${ }^{e 8}$ The distinction falls completely once the highest court of a state holds that application of the full faith and credit clause would be obnoxious to its policy of affording an injured workman a tort recovery.

en "The Pacific Employers Insurance Co. case allowed the Compensation Act of the place of the injury to override the Compensation Act of the home State. Here it is a common-law action that is asserted against the exclusiveness of the remedy of the home State; and that is seized on as marking a difference. That is not in our judgment a material difference." Carroll v. Lanza, 349 U.S. 408, 412 (1955). 
with the employment is significant, and if the forum is the state of injury Carroll allows the forum to apply a rigid rule and refuse to apply the statute of another state..$^{70}$ As the forum may, if it wishes, apply its own law in an employee-employer tort action whenever the injury occurs within its borders, the Clapper case is overruled insofar as it compels application of the contractstate's statute.

Nevertheless, the state of injury in a tort action need not apply its own law, but if it chooses, may apply the contract-state's statute under the full faith and credit clause. When as in the Clapper case, a federal court is sitting in an injury-state which has not declared a public policy by previous decision, ${ }^{71}$ the Clapper result is still proper. The rationale of such a result, however, will follow that of Justice Stone in his concurring opinion in the Clapper case. In the absence of a state court decision to the contrary, the federal court may presume that the state court would, under the full faith and credit clause, apply the contract-state's statute. ${ }^{72}$ However, in the ordinary employee-employer common-law tort action, it may be concluded that the Supreme Court will no longer require a state to subordinate its policy to that of another state by rigid application of the full faith and credit clause.

${ }^{70}$ This comment has been primarily concerned with an analysis of decisions of the Supreme Court in cases involving workmen's compensation conflict-of-laws problems for the purpose of determining the proper disposition of cases not yet passed on by the Supreme Court. No attempt has been made to discuss the desirability of a rigid rule applicable in all cases of workmen injured within the forum. Justice Douglas' position in establishing such a rule was: "Her [Arkansas] interests are large and considerable and are to be weighed not only in the light of the facts of this case but by the kind of situation presented. For we write not only for this case and this day alone, but for this type of case. . . . Arkansas therefore has a legitimate interest in opening her courts to suits of this nature, even though in this case Carroll's injury may have cast no burden on her or on her institutions." Carroll v. Lanza, 349 U.S. 408, 413 (1955). Compare the dissent of Justice Frankfurter: "Unlike the other workmen's compensation cases-or, for that matter, any of the cases in which the forum has prevailed in a conflict between the forum and the outside law-the interest of the forum here is solely dependent on the occurrence of the injury within its borders. No rights of Arkansas residents are involved, since none of the parties is an Arkansan; the workman was removed immediately to a Missouri hospital and has, so far as appears, remained in Missouri. What might be regarded as the societal interest of Arkansas in the protection of the bodily safety of workers within its borders is an interest equally true of any jurisdiction where a workman is injured. . ." Ibid., at 420-21. Discussion of these two opposing attitudes necessarily involves the entire theory of our federal system, the role of the Supreme Court within the federal system, and the extent of conflict between certainty and justice in the law. Suggested references are Cheatham, Federal Control of Conflict of Laws, 6 Vand. L. Rev. 581 (1953); Jackson, Full Faith and Credit-The Lawyer's Clause of the Constitution, 45 Col. L. Rev. 1 (1945); The Supreme Court, 1954 Term, 69 Harv. L. Rev. 119, 133-38 (1955); and authorities contained therein.

${ }^{71}$ In Carroll v. Lanza, 116 F. Supp. 491 (1953) the district court found that Arkansas had declared such a public policy by previous decision. Consult note 8 supra.

${ }^{72} \mathrm{Mr}$. Justice Stone in his concurring opinion in the Clapper case phrased this position somewhat differently by indicating that the federal court may presume the state court would, as a matter of "comity," apply the contract-state's statute. Bradford Electric Co. v. Clapper, 286 U.S. 145, 163 (1932). 